DOI 10.22460/infinity.v6i2.p121-136

\title{
PRE-SERVICE MATHEMATICS TEACHERS' CONCEPTION OF HIGHER-ORDER THINKING LEVEL IN BLOOM'S TAXONOMY
}

\author{
Damianus D. Samo \\ Nusa Cendana University, Jalan Adisucipto Penfui, Kupang, Indonesia \\ demm_samo@yahoo.com
}

Received: April 06, 2017 ; Accepted: May 01, 2017

\begin{abstract}
The purpose of this study is to explore pre-service mathematics teachers' conception of higher-order thinking in Bloom's Taxonomy, to explore pre-service mathematics teachers' ability in categorizing six cognitive levels of Bloom's Taxonomy as lower-order thinking and higher-order thinking, and preservice mathematics teachers' ability in identifying some questionable items as lower-order and higher-order thinking. This research is a descriptive quantitative research. The participants are 50 Third-Year Students of Mathematics Education Department at Universitas Nusa Cendana. The results showed: (1) pre-service mathematics teachers' conception of lower-order and higher-order thinking more emphasis on the different between the easy and difficult problem, calculation problem and verification problem, conceptual and contextual, and elementary and high-level problem; (2) preservice mathematics teachers categorized six cognitive levels at the lower-order and higher-order thinking level correctly except at the applying level, preservice mathematics teachers placed it at the higher-order thinking level; (3) pre-service mathematics teacher tend to made the wrong identification of the test questions that were included in the lower-order and higher-order thinking.
\end{abstract}

Keywords: Bloom's taxonomy, Higher-order thinking.

\begin{abstract}
Abstrak
Tujuan penelitian ini adalah untuk mengeksplorasi konsepsi calon guru matematika tentang higher order thinking dalam taksonomi Bloom, mengeksplorasi kemampuan calon guru matematika dalam mengkategorikan enam level kognitif dalam Taxonomi Bloom sebagai lower order thinking dan higher order thinking, dan kemampuan calon guru matematika dalam mengidentifikasi item test sebagai lower order thinking dan higher order thinking. Penelitian ini adalah penelitian deskripstif kuantitatif. Subjek penelitian adalah 50 mahasiswa tingkat tiga di Jurusan Pendidikan Matematika, Fakultas Keguruan dan Ilmu pendidikan, Universitas Nusa Cendana. Hasil penelitian menunjukan bahwa: (1) konsepsi calon guru matematika tentang lower-order thinking dan higher-order thinking lebih menekankan pada perbedaan tingkatan masalah yang sulit dan mudah, masalah perhitungan dan pembuktian, konseptual dan kontekstual, tingkat berpikir elementer dan tingkat berpikir lanjut; (2) calon guru matematika mengkategorisasikan enam level kognitif pada level lower-order thinking dan higher-order thinking secara tepat kecuali pada level aplikasi, banyak calon guru matematika yang menempatkannya pada level higher-order thinking; (3) calon guru matematika cenderung salah mengidentifikasi soal test yang termasuk dalam lower order thinking dan higher-order thinking.
\end{abstract}

Kata Kunci: Higher order thinking, Taksonomi Bloom

How to Cite: Samo, D. D. (2017). Pre-Service Mathematics Teachers' Conception of HigherOrder Thinking Level in Bloom's Taxonomy. Infinity, 6 (2), 121-136. doi:10.22460/infinity.v6i2.p121-136 


\section{INTRODUCTION}

The National Educational Goal is to develop the potential of students' to become a man of faith and fear of God Almighty and noble, healthy, knowledgeable, skilled, creative, independent, and become citizens of a democratic and responsible. This national educational goal contains two important aspects that are cognitive and attitude aspects. Cognitive aspect emphasizes proficient and creative. Proficient in The Indonesian big dictionary is 1) capable of doing something; 2) clever, proficient; 3 ) have the ability and skill to grind. The definition shows that proficient is more than just remembering. Being able to do something means having the knowledge, understanding, and skill enough in doing the job. This condition shows that proficient is not enough based on the usual way of thinking but requires a higher way of thinking to work in all situations or problems. While creative means 1) have created; can create; 2) contains creativity, work that requires intelligence and imagination. Creative is the highest level in the taxonomy of education or a part of a higher-order thinking level. Therefore, the National Educational goal requires that learning should be developed and designed to develop higher-order thinking ability.

Bloom, Engelhart, Hill, Furst, \& Krathwhol (1956) divided the taxonomy of educational into six levels: (1) knowledge; (2) comprehension; (3) application; (4) analysis; (5) synthesis and (6) evaluation. The sixth level is grouped into two major parts, namely, lower order thinking (knowledge, comprehension, and application) and higher-order thinking (analysis, synthesis, and evaluation). Bloom's taxonomy is revised by Anderson \& Kratwohl (2001) and brings new educational taxonomy into (1) remembering; (2) understanding; (3) applying; (4) analyzing; (5) evaluating, and (6) creating. The aspects of higher-order thinking in the taxonomy are revised: (1) analyzing; (2) evaluating; and (3) creating. The last three levels which are defined as higher-order thinking have many attributes or characteristics that distinguish one another; allows the use as a part in learning activities in both the process and its evaluation. Analyzing is associated with cognitive processes by giving, attributing, organizing, integrating and validating. Evaluating includes checking, critiquing, hypothesizing, and experimenting. Creating includes generating, designing, producing, and devising.

Some experts define higher-order thinking by referring to Bloom's Taxonomy revisions to mention higher-order thinking as the ability to think analytic, evaluative and creative (Pegg, 2010; Thompson, 2000). Thompson (2000) defined higher-order thinking involves solving tasks where an algorithm has not been taught or using known algorithms while working in unfamiliar contexts or situations. The definitions stated above imply higher-order thinking as problem-solving activities. Aside from being a problem-solving activity, some authors present some additional attributes: the ability to think critically and creatively (Brookhart, 2010; Miri, David, \& Uri, 2007). The addition attributes critical and creative thinking skills showed an understanding that aspect of problem-solving has a broad scope so it can be analyzed into small parts that show the other thinking skills that can be developed. Moreover, some experts also define higher-order thinking by showing many of the attributes that is, as the ability to solve problems that involve critical thinking, logical, reflective, metacognition, reasoning, and creative (Lewis \& Smith, 1993; Murray, 2011). Higher-order thinking in this research is a non-algorithms thinking include analytical, evaluative and creative thinking which involves metacognition.

The importance of developing higher-order thinking has some reasons: (1) to organize knowledge learned into long-term memory. Organizing raises enough information retention 
longer than if stored in short-term memory that is characteristic of lower order thinking. For example, students who learn to memorize tend to quickly forget what is memorized than students who learned how to discover. Memorization process will push that knowledge into short-term memory, while the process of discovering will push that knowledge into long-term memory. Knowledge stored in long-term memory is easily accessed and is used in various situations that tend to change: (2) to develop adaptability to a variety of new problems that is found in life, exercises to develop a higher order thinking ability in formal education will develop an attitude and a way of creative thinking to get out of life's problems are complex, (3) to encourage the creation of quality human resources that can compete with other nations.

In connection with the importance of developing the higher-order thinking ability, then the teacher as a major subject in learning should be able to design learning that accommodates strategy of developing higher-order thinking ability. The strategies of developing higher-order thinking are using the contextual problem, using the test items of higher-order thinking, asking and discuss the critical and analytical problem, and encourage students to develop ideas and think out of context. Teacher's ability in designing the learning activities should be based on an understanding of higher-order thinking itself.

A complete understanding of higher-order thinking in the bloom taxonomy aims to support preservice teachers in the development of problem-solving and mathematics ability. Delima (2017) reveals there is an influence of problem-solving ability to students mathematical thinking. Furthermore, a good understanding of Bloom Taxonomy will support preservice mathematics teachers in constructing questions to access students' thinking ability. Asking a question requires good communication skills so that the message is a question of the mastery of good grammar, that of the material, and communicative skills (Hendriana, 2017). Questions expressed in addition to clear must be analytical, critical, and can be imaginative expressions.

Higher order thinking in the Bloom's Taxonomy is a skill that can be trained to secondary school students and university students. Higher-order thinking at the university level is better known as advanced mathematical thinking because of the substance of the material at the advanced level. Advanced mathematical thinking includes ability in representing, abstracting, creative thinking, and mathematical proving (Herlina, 2015). So here, there are many impacts of a good conception of the higher-order thinking and lower order thinking of bloom taxonomy. A good understanding should be given to pre-service mathematics teachers as teachers in the future. The understanding can be given in the course of learning evaluation of learning and in other courses through the introduction of problem according to the cognitive level of Bloom's Taxonomy and discussion in the learning activities.

Therefore, in this study, I will explore pre-service mathematics teachers' conceptions of higher-order thinking in Bloom's Taxonomy and the results of exploration can be a reference in preparing pre-service teachers to become a teacher of the future. Exploration is done on final year students who have been equipped with learning evaluation courses and subjects supporting pedagogy. So that the problem in this research are; 1) how do pre-service mathematics teacher's conceptions of lower-order and higher-order thinking in Bloom's Taxonomy?, 2) how do pre-service mathematics teachers categorize six cognitive levels of Bloom's Taxonomy as lower-order and higher-order thinking, 3) how do pre-service mathematics teachers identify the test as lower-order and higher-order thinking?. The benefit got with this exploration is to inform pre-service teacher mathematics educators in the 
decision to equip pre-service mathematics teachers with the knowledge and understanding of the Bloom's Taxonomy completely in classroom learning implementation.

\section{METHOD}

This research is a descriptive quantitative study. The data were analyzed and visualized by percentages and diagrams. The participants are 50 third-year students of Mathematics Education Department at Universitas Nusa Cendana. The instruments used in this study were questions items and interview guideline. The question items are: (1) the preservice mathematics teachers' conception of lower-order and higher-order thinking in Bloom's taxonomy, (2) the cognitive domain classification of six major categories, and (3) the identification of lower-order and higher-order thinking questions. The third question items presented several linear equations and functions questions of 7 th and 8th-grade mathematics which have all six categories of Bloom's taxonomy. Based on the synthesis of experts', lowerorder and higher-order thinking definition are;

1) Lower-order thinking is the type of algorithm thinking or simple thinking that follows existing pattern or procedures. In Bloom's taxonomy, lower-order thinking includes remembering, understanding, and applying. The remembering level question is using the information retrieval in one simple step and wrote down directly what it is. The understanding level question involves recognizing or remembering information in one step and well explained. The applying level question involves using acquired knowledge in one step and applying the information to solve the problem with correct procedures.

2) Higher-order thinking is the type of non-algorithm thinking which include analytic, evaluative and creative thinking that involves metacognition. In this context, problemsolving question belongs to the higher-order thinking question which can be reflected in analyzing, evaluating, and creating. The analyzing level is problem-solving question whereby solution does not use the information (formulas, rules or procedures) directly but instead use other additional supporting information. The evaluating level question is problem-solving question containing elements of decision making. In mathematics context, the decision can be considered as the correct or incorrect of given information or statement, or the examination procedures of results of problem-solving. The creating level question is problem-solving question containing orders or commands to create something new as clue or guidance to solve the next problem.

\section{RESULTS AND DISCUSSION}

\section{Results}

The following are the research results and are organized according to the research question:

\section{Pre-service mathematics teachers' conception of higher-order thinking}

Subjects wrote different conceptions of lower-order thinking and higher-order thinking based on their understanding. Most of the subjects wrote that lower-order thinking is thinking ability on easy problems, whereas higher-order thinking is thinking about difficult problems. A subject wrote that lower-order thinking is the ability to remember the concepts while higherorder thinking is problem-solving ability level. Another subject wrote that lower-order thinking is elementary school problems and higher-order thinking is high school problems.

Some conception of higher order thinking and lower order thinking is shown in the following figure: 

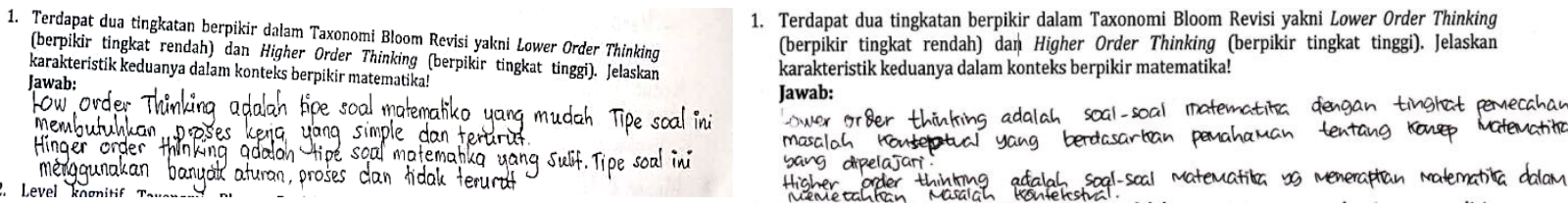

Figure 1. Subjects' Conception

The summary of subjects' conceptions can be shown as follows:

Table 1. The Summary of Subjects' Conception Description

\begin{tabular}{|c|c|}
\hline Lower-order thinking & Higher-order thinking \\
\hline Easy level problems & Difficult level problems \\
\hline Ability to remember the concepts & Using existing concepts to solve problems \\
\hline Use understanding in problem-solving & $\begin{array}{l}\text { Developing an existing understanding in solve the } \\
\text { complex problem. }\end{array}$ \\
\hline Not making a mathematical model & Making mathematical model \\
\hline Simple thinking level that uses a part of the brain & Complex thinking level that uses all the brains \\
\hline Elementary school problem thinking & High school problems thinking \\
\hline Problem-solving with little step procedures & Problem-solving with many step procedures \\
\hline Calculation problem thinking & Verification problem thinking \\
\hline Solve concept problems & Solve word or contextual problems \\
\hline
\end{tabular}

The summary of subjects' conceptions of lower-order thinking and higher-order thinking is more emphasis on the different between the level of easy and difficult problem, calculation problem and verification problem, conceptual and contextual, and elementary and high level. Subjects' conceptions have touched on lower-order thinking and higher-order thinking description yet as two different cognitive processes level at procedural and nonprocedural or algorithm and nonalgorithmic. Some subjects construe the difference in making mathematical models and not. Mathematical modeling is a characteristic of the understanding level. On the other hand, misconceptions arise at the distinction in calculation and verification. Verification is a part of higher-order thinking in analyzing level; however, the calculation is at higherorder thinking and lower-order thinking level. Misconceptions also seem at the distinction in lower-order thinking and higher-order thinking characteristic which at the conceptual and contextual problem. Contextual problems are considered as higher-order thinking problems even though those problems apply the formula which is known directly. Subjects' misconceptions impact on the formulation of higher-order thinking mathematics problems.

In order to strengthen the conception of lower order thinking and higher order thinking Bloom's taxonomy students' written answer, then interviewed several subjects. The results of interviews on the written answers of the two subjects above are presented as follows:

$R \quad$ : You write down the characteristics of lower order thinking and higher order thinking based on different levels of easy and difficult questions. What is the reason?

S1 : I understand that lower order thinking is a simple type of thinking that certainly in doing math problems does not require long and difficult process while higher order thinking otherwise.

$R \quad$ : Could you explanation it more concrete?

$S 1$ : I mean, the lower order thinking problem is asked to solve the math problem directly, for example, find the roots of quadratic equation, this is easy and not a long process. Compare with the matter of quadratic equations but in story form. 
$R \quad$ : Lower order thinking and higher order thinking characteristics you write that is conceptual and contextual problem solving. Why is that?

S2 : Lower order thinking works on the realm of facts or concepts. This means we're only asked to solve the problem by mentioning concepts we remember from what we've learned before.

$R \quad$ : What about higher order thinking?

$S 2$ : Higher order thinking is more complex, we are asked to use the concepts we remember or mention it to solve the contextual problems we encounter.

\section{Pre-service mathematics teachers' conception of six cognitive levels}

The second research question is how preservice mathematics teachers categorize six cognitive levels of Bloom's Taxonomy as a lower-order thinking and higher-order thinking. Subjects provided six cognitive levels of Bloom's Taxonomy and identified at lower-order thinking and higher-order thinking level.

Some categorization of higher order thinking and lower order thinking is shown in the following figure:

2. Level kognitif Taxonomi Bloom Revisi adalah mencipta, mengevaluasi, menganalisis, mengaplikasi, memahami dan mengingat. Kategorikan keenam level tersebut dalam level lower order thinking dan higher order thinking dan berikan alasan mengapa anda mengkategorikan demikian. Jawab:

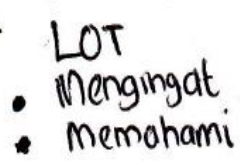

HOT

- Mengaplitarí

- Menganalises

- Mengevaluaf

- mencipta

2. Level kognitif Taxonomi Bloom Revisi adalah mencipta, mengevaluasi, menganalisis, mengaplikasi, memahami dan mengingat. Kategorikan keenam level tersebut dalam level lower order thinking dan higher order thinking dan berikan alasan mengapa anda mengkategorikan demikian.

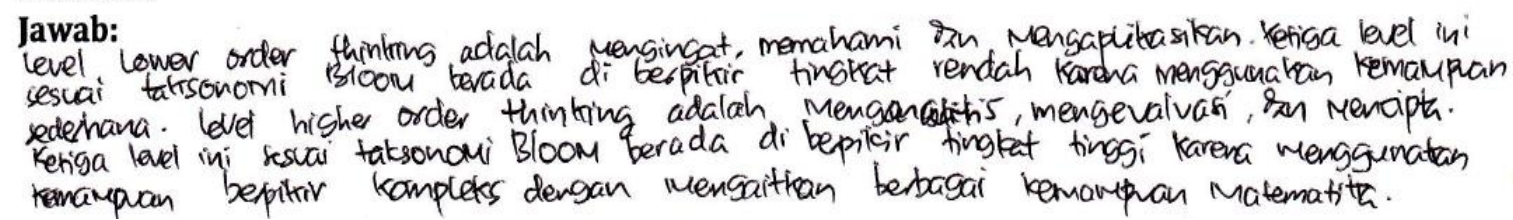

Figure 2. Subjects' Categorization

Those results are presented as follow:

Table 2: The Percentage of Subjects' Categorization Results

\begin{tabular}{lrlrl}
\hline \multirow{2}{*}{ Cognitive Level } & \multicolumn{4}{c}{ Percentage } \\
\cline { 2 - 5 } & \multicolumn{1}{c}{ Lower-order thinking } & Higher-order thinking \\
\hline Remembering & 50 & $(100 \%)$ & 0 & $(0 \%)$ \\
Understanding & 38 & $(76 \%)$ & 12 & $(24 \%)$ \\
Applying & 16 & $(32 \%)$ & 34 & $(68 \%)$ \\
Analyzing & 10 & $(20 \%)$ & 40 & $(80 \%)$ \\
Evaluating & 8 & $(16 \%)$ & 42 & $(84 \%)$ \\
Creating & 0 & $(0 \%)$ & 50 & $(100 \%)$ \\
\hline
\end{tabular}




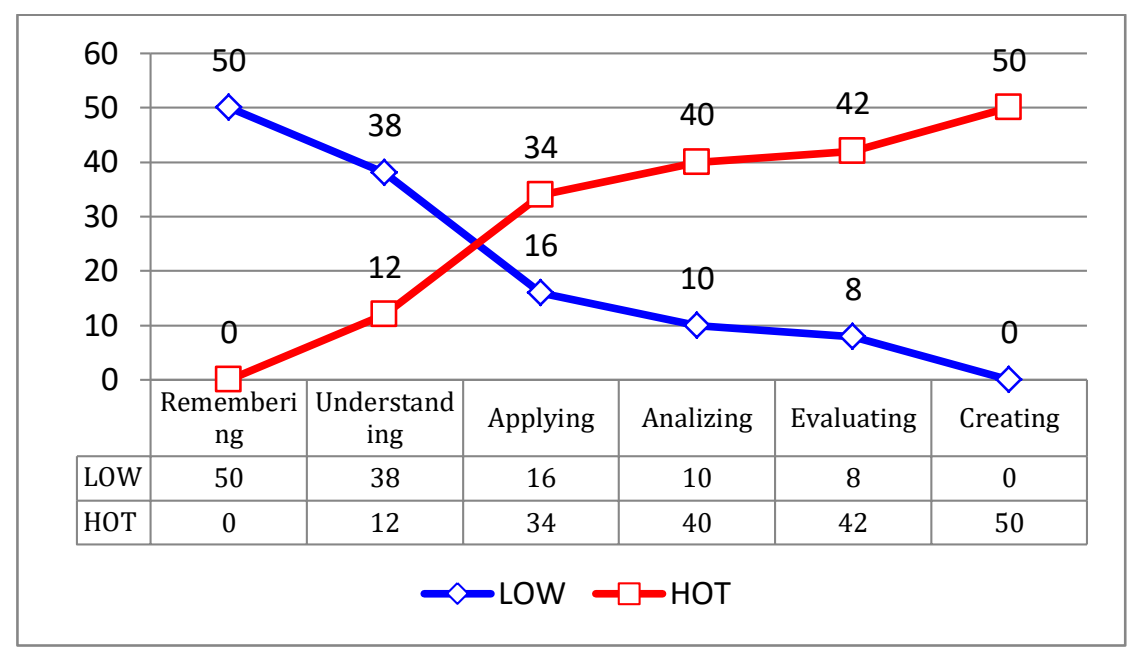

Figure 3. Subjects' Categorization Results

Based on the Table, all of the students categorize the remembering level in lower order thinking and creating in higher order thinking. In understanding level, $76 \%$ subjects categorize in lower order thinking and $12 \%$ categorize in higher order thinking. In analyzing level, $20 \%$ subjects categorize in lower order thinking and $80 \%$ subjects categorize in higher order thinking. In evaluating level, $16 \%$ subjects categorize in lower order thinking and $84 \%$ subjects categorize in higher order thinking. The subjects' categorization of lower-order thinking and higher-order thinking on above table showed that subjects made a mistake when they placed applying level at higher-order thinking. These conditions accordance with the exploration results at the first research question where many subjects mentioned that higherorder thinking as a type of solving contextual or word problem. In quantitative terms, application level is interpreted as higher-order thinking level, qualitative exploration to obtain any information why subjects categorize applying level at higher-order thinking would be explained on qualitative research later.

To explore the results of lower order thinking and higher order thinking Bloom's taxonomy conception then conducted interviews on several subjects. The results of interviews on the written answers of two subjects above are presented as follows:

$R \quad$ : You put remembering and understanding in lower order thinking while others are in higher order thinking. What is your explaination?

S1 : Actually, I forgot about dividing the taxonomy level of bloom but based on my intuition, remembering and understanding it requires a simple process. As I said before that the lower order thinking is a simple process, not complicated and not long.

$R \quad$ : What about the other four levels you categorized in higher order thinking?

$S 1$ : Because higher order thinking need a long and complicated process then the matter of applying level and the other exactly categorized in higher order thinking. This is because, at the level of this problem we work on the problem with a long work process, using many concepts and difficult.

$R \quad$ : You put remembering, understanding and applying in lower order thinking level while analyzing, evaluating and creating in higher order thinking. What is your explanation?

$S 2$ : In Bloom's revision taxonomy, distinguished in two levels of lower order thinking and higher order thinking with the cognitive level I wrote this. In my opinion, the first three levels as lower order thinking require simple cognitive work, whereas higher order thinking requires more complex cognitive work because it involves many related concepts in contextual problem solving. 
$R \quad: \quad$ Many of your friends put applying into higher order thinking. What is your opinion about that?

S2 : The applying is related to the use of formulas or rules directly so it does not require complex cognitive work.

$R \quad$ : Can you give an example to prove your answer?

$S 2$ : In example we are asked to find the length of one side of the right triangle if we know the length of two other sides then we use the formula phytagoras directly. This is easy. So this is an applying level.

Pre-service mathematics teachers' identification of lower-order and higher-order thinking questions.

The third research question is how pre-service mathematics teachers identify tests items as the lower-order thinking and higher-order thinking in one-variable linear equations and function. The tests items are shown as follows:

\section{Section I (one-variable linear equations)}

1. The sum of three consecutive even numbers is 48 . What are these numbers?

2. What is an open sentence?

3. Write the one-variable linear equation form of following sentence: "the sum of twice of y and $(-5)$ is 21 "'

4. Find the solution set of $5 x=x-40$

5. Find the mistake in solving one-variable linear equations

$2 \mathrm{x}=11 \mathrm{x}+45$

$2 \mathrm{x}-11 \mathrm{x}=11 \mathrm{x}-11 \mathrm{x}+45$

$9 \mathrm{x}=45$

$\frac{9 x}{9}=\frac{45}{9}$

$\mathrm{x}=5$

6. Write the real-world phrase as a variable expression: $2 x+5=6$

7. Write an equation with the solution $\mathrm{x}=2$, the equation should have the variable on both sides

8. A car and a motorcycle set off from the same point to travel the same journey. The car has a start of four minutes before the motorcycle sets off. If the car travels at $80 \mathrm{~km} / \mathrm{h}$ and the motorcycle travels at $90 \mathrm{~km} / \mathrm{h}$, how many kilometers will be traveled when the two vehicles are level?

Some identification result of cognitive level is shown in the following figure: 


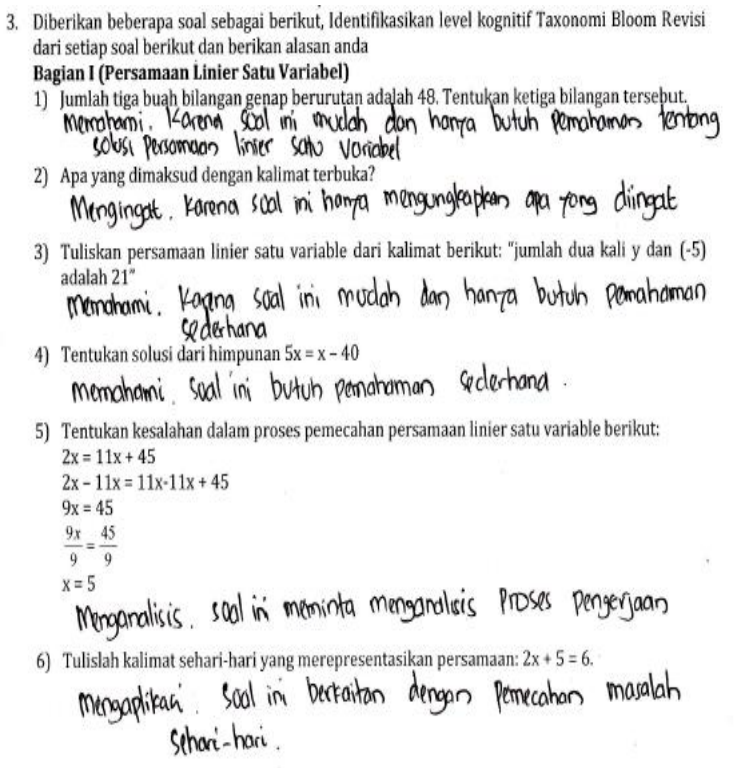

3. Diberikan beberapa soal sebagai berikut, Identifikasikan level kognitif Taxonomi Bloom Revisi dari setiap soal berikut dan berikan alasan anda

Bagian I (Persamaan Linier Satu Variabel)

1) Jumlah tiga buah bilangan genap berurutan adalah 48 . Tentukan ketiga bilangan tersebut

uengaplitasi. Soal ini menerapkan ohwon matemativa setara prosedural.

2) Apa yang dimaksud dengan kalimat terbuka?

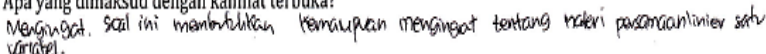

3) Tuliskan persamaan linier satu variable dari kalimat berikut: "jumlah dua kali y dan (-5)

adalah $21^{\prime \prime}$

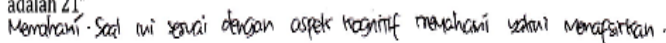

4) Tentukan solusi dari himpunan $5 x=x-40$ mengapliteaskean. Soal ini mereraptran aturan matematika secara prosededal utuk (mencari vilai $X$.

5) Tentukan kesalahan dalam proses pemecahan persamaan linier satu variable berikut: $2 x=11 x+45$

$2 x-11 x=11 x-11 x+45$

$9 \mathrm{x}=45$

$\frac{9 x}{9}=\frac{45}{9}$

$\frac{9 x}{9}=\frac{45}{9}$

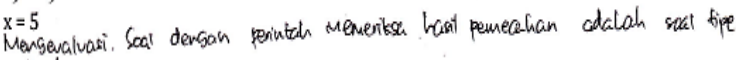
exaluasi

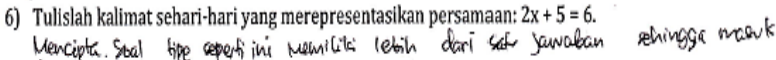
dalar revel inentipte.

Figure 4. Subjects' Identification

Identification results that are presented as follow:

Table 3. Levels Categorization Results

\begin{tabular}{ccccccc}
\hline \multirow{2}{*}{$\begin{array}{c}\text { Question } \\
\text { items }\end{array}$} & \multicolumn{6}{c}{ Cognitive Level of Bloom's Taxonomy } \\
\cline { 2 - 7 } & $\mathbf{C 1}$ & $\mathbf{C 2}$ & $\mathbf{C 3}$ & $\mathbf{C 4}$ & $\mathbf{C 5}$ & $\mathbf{C 6}$ \\
\hline $\mathbf{1}$ & 2 & 8 & 22 & 12 & 5 & 1 \\
$\mathbf{2}$ & 30 & 16 & 3 & 1 & 0 & 0 \\
$\mathbf{3}$ & 11 & 20 & 17 & 2 & 0 & 0 \\
$\mathbf{4}$ & 9 & 18 & 15 & 8 & 0 & 0 \\
$\mathbf{5}$ & 0 & 1 & 12 & 15 & 12 & 10 \\
$\mathbf{6}$ & 1 & 12 & 2 & 13 & 5 & 17 \\
$\mathbf{7}$ & 0 & 8 & 11 & 15 & 0 & 16 \\
$\mathbf{8}$ & 0 & 6 & 35 & 7 & 2 & 0 \\
\hline Total & 53 & 89 & 117 & 73 & 24 & 44 \\
\hline
\end{tabular}

\section{Categorization}

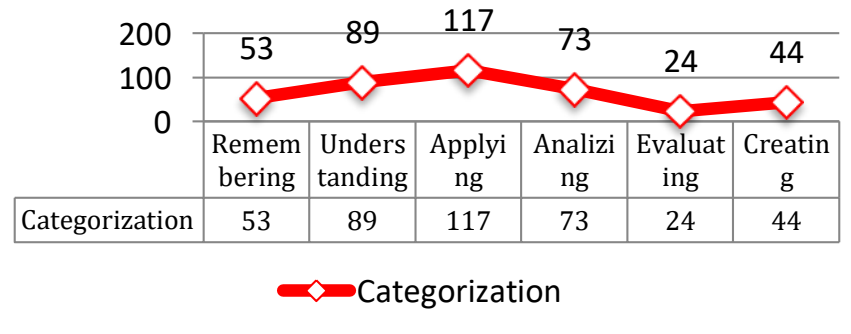

Figure 5. Subjects' Categorization Results 
The first section presented higher-order thinking question at number 5, 6, 7 and 8 . The fifth questions are identified differently by subjects. Question number one is applying level, 44\% subjects identified as applying level and 24\% subjects identified as analyzing level. Question number 5 is evaluating level, 74\% subjects identified as higher-order thinking level, 30\% subjects identified as analyzing level and 24\% subjects identified as evaluating level. Question number 6 and 7 are creating level, 34\% subject identified as creating level at number 6 dan 32\% subject identified as creating level at number 7 whereas, there are still many subjects that categorize at analyzing level. What is interesting is at the question number 8 , about $70 \%$ subjects identified as applying level. In general, eight questions that are presented above, the majority of subjects categorized them in the applying level. If we review the group higher-order thinking and lower-order thinking then students categorize $64.75 \%$ in lowerorder thinking category. This condition in accordance with the subject's conception which subjects'described higher-order thinking as the word or contextual problem.

\section{Section 2 (Function)}

1. Given a function $g(x)=a x+7$. The value of $g(x)$ for $x=-2$ is 1 . Find the value of $g(x)$ for $x=5$. Find the equation of $g(x)$. Describe your ways.

2. Given a function $\mathrm{f}(\mathrm{x})=2 \mathrm{x}-3$ with the domain of $\mathrm{f}(\mathrm{x})$ is $\mathrm{A}=\{7,9,11,13\}$ and a function dan fungsi $\mathrm{g}(\mathrm{x})=3 \mathrm{x}+4$ with the domain $\mathrm{P}=\{\mathrm{x} \mid \mathrm{x} \geq 3, \mathrm{x} \in R\}$. Compare the two graphs the functions, what can you conclude?

3. What are relation and function?

4. Two graphs of function are parallel if the comparison of variable $\mathrm{x}$ and the comparison of variable $\mathrm{y}$ are equal. Whereas two graphs of function coincide if the comparison of variable $\mathrm{x}$, the comparison of variable $y$ and if the comparison of coefficient is equal. Whether the information is correct?

5. Draw an arrow diagram to represent the function that related from a set of $\mathrm{A}$ to $\mathrm{B}$. If $\mathrm{R}$ is a relation 'is greater than' from A to B.

6. Given a function $\mathrm{f}(\mathrm{x})=-\mathrm{x}+3$ with the domain $\mathrm{K}=\{-3,-1,1,3,5,7\}$

- Repersent $\mathrm{f}(\mathrm{x})$ diagramatically

- Find the value of $f(x)$ for $x=-3, x=5$

- Find the range of $f(x)$.

7. Given $A=\{p, q, r\}$ and $B=\{2,3,4\}$. Draw all the possible mapping from set $A$ to set $B$ with arrows diagram

Some identification result of cognitive level is shown in the following figure: 


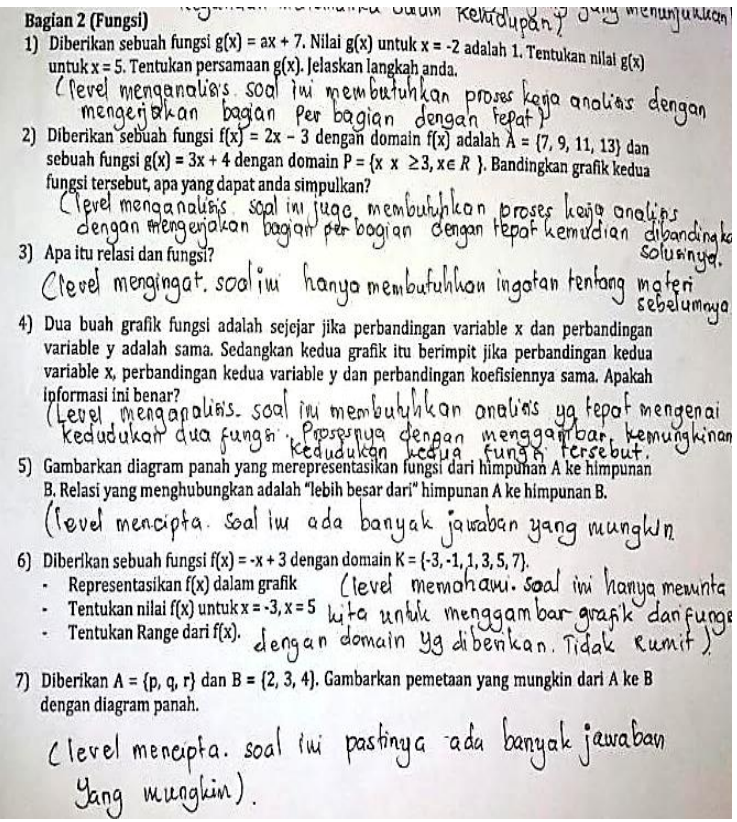

Bagian 2 (Fungsi)

1) Diberikan sebuah fungsi $g(x)=a x+7$. Nilai $g(x)$ untuk $x=-2$ adalah 1 . Tentukan nilai $g(x)$ untuk $x=5$. Tentukan persamaan $g(x)$. Jelaskan langkah anda

untuk $x=5$. Tentukan persamaan $g(x)$. Jelaskan langkah anda. sectira langsing

2) Diberikan sebuah fungsi $f(x)=2 x-3$ dengan domain $f(x)$ adalah $A=\{7,9,11,13\}$ dan sebuah fungsi $g(x)=3 x+4$ dengan domain $P=\{x \quad x \geq 3, x \in R\}$. Bandingkan grafik kedua

fungsi tersebut, apa yang dapat anda simipulkan?

3) Apa itu relasi dan fungsi? membrivitan lemampan mengivat tentang maten relaś dan frugs:

4) Dua buah grafik fungsi adalah sejejar jika perbandingan variable $x$ dan perbandingan variable y adalah sama. Sedangkan kedua grafik itu berimpit jika perbandingan kedua variable $x$, perbandingan kedua variable y dan perbandingan koefisiennya sama. Apakah informasi ini benar?

mameghan mosiah thi addiah dengan menggambar atac menbentuts dua persomaan sesual kniteria dan mengavaluastuna.

5) Gambarkan diagram panah yang merepresentasikan fungsi dari himpunan $A$ ke himpunan B. Relasi yang menghubungkan adalah "lebih besar dari" himpunan A ke himpunan B.

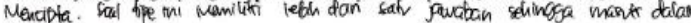
lovel Mentada.

6) Diberikan sebuah fungsi $f(x)=-x+3$ dengan domain $K=\{-3,-1,1,3,5,7\}$.

- Representasikan $\mathrm{f}(\mathrm{x})$ dalam grafik

Tentukan nilai $\mathrm{f}(\mathrm{x})$ untuk $\mathrm{x}=-3, \mathrm{x}=5$

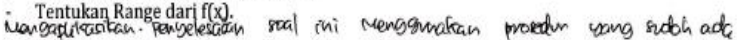

7) Diberikan $A=\{p, q, r\}$ dan $B=\{2,3,4\}$. Gambarkan pemetaan yang mungkin dari $A$ ke $B$ dengan diagram panah.

Mencipta. Soat tipe seperti ini memiliter lebin dari satr jawlaban sehingsa masuk ralam level menapta.

Figure 6. Subjects' Identification

The result of identification are presented below:

Table 4. Levels Categorization Results

\begin{tabular}{ccccccc}
\hline \multirow{2}{*}{$\begin{array}{c}\text { Question } \\
\text { items }\end{array}$} & \multicolumn{6}{c}{ Cognitive Level of Bloom's Taxonomy } \\
\cline { 2 - 7 } & $\mathbf{C 1}$ & $\mathbf{C 2}$ & $\mathbf{C 3}$ & $\mathbf{C 4}$ & $\mathbf{C 5}$ & $\mathbf{C 6}$ \\
\hline $\mathbf{1}$ & 0 & 3 & 16 & 18 & 12 & 1 \\
$\mathbf{2}$ & 0 & 1 & 19 & 23 & 7 & 0 \\
$\mathbf{3}$ & 27 & 20 & 2 & 1 & 0 & 0 \\
$\mathbf{4}$ & 0 & 1 & 5 & 23 & 20 & 1 \\
$\mathbf{5}$ & 0 & 13 & 19 & 12 & 5 & 1 \\
$\mathbf{6}$ & 0 & 1 & 20 & 15 & 6 & 8 \\
$\mathbf{7}$ & 1 & 1 & 15 & 11 & 10 & 12 \\
\hline Total & 28 & 40 & 96 & 103 & 60 & 23 \\
\hline
\end{tabular}

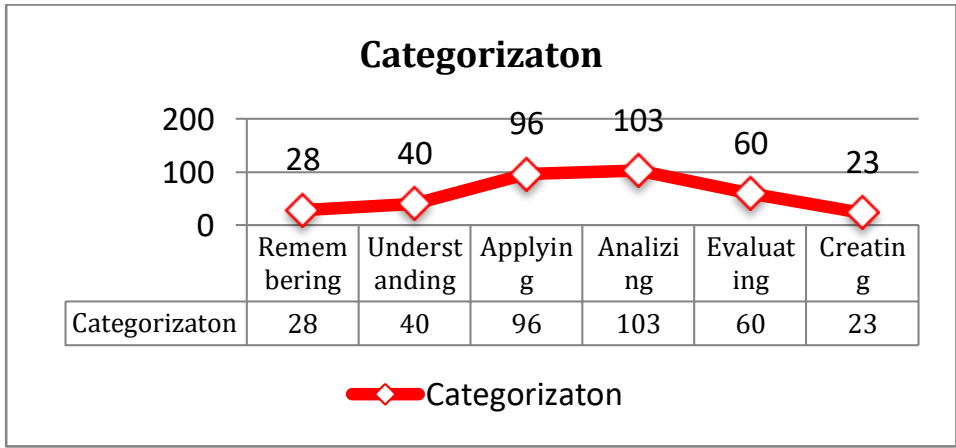

Figure 7. Subjects' Categorization Results

The second section presented higher-order thinking question at number 1, 2, 4, 5 dan 7. The fifth questions are identified differently by subjects. Question number 1 and 2 are analyzing 
level. From both questions, more than $90 \%$ subjects identified as higher-order thinking level, $36 \%$, and $46 \%$ subjects answered correctly as analyzing level. Question number 4 is evaluating level, $46 \%$ subjects identified as higher-order thinking at analyzing level and $40 \%$ at evaluating level. Question number 5 is creating level, 36\% subjects identified as higherorder thinking with details $24 \%$ categorize at analyzing level, $2 \%$ subjects located at creating level, while 38\% identified as applying level. Question number 7 is creating level, 24\% subjects identified as creating level whereas $30 \%$ identified as applying level. In general, nine questions that are presented above, majority of subjects categorized them in the analyzing level. If we review the group higher-order thinking and lower-order thinking then students categorize $64.75 \%$ in higher-order thinking category.

\section{Discussion}

The purpose of this study is to explore pre-service mathematics teachers' conception of higher-order thinking in Bloom's Taxonomy, categorization six cognitive levels of Bloom's Taxonomy as lower-order and higher-order thinking, and identification some question items as lower-order and higher-order thinking.

This research reveals preservice mathematics teachers' conceptions of higher-order thinking in Bloom's Taxonomy that inclined erroneous. Pre-service mathematics teachers' conception of lower-order and higher-order thinking more emphasis on the different between the easy and difficult problem, calculation problem and verification problem, conceptual and contextual, and elementary and high-level problem. Pre-service mathematics teachers categorized six cognitive levels at the lower-order and higher-order thinking level correctly except at the applying level, preservice mathematics teachers placed it at the higher-order thinking level. Subjects categorize remembering and understanding level in lower order thinking whereas applying until creating in higher order thinking. These categorization base on their intuition and learning experience that mention the word problem as application question and the application question is problem-solving question. Word problem question and problemsolving question are two different things. Word problem can be categorized in problemsolving question and applying level question. The problem-solving question is not merely the word problem. In other sections, pre-service mathematics teacher tend to made the wrong identification of the test questions that were included in the lower-order and higher-order thinking.

Bloom's Taxonomy is something that is very familiar to the preservice mathematics teachers but not understood deeply. According to Coffman (2013), although the preservice teachers have heard of Bloom's Taxonomy, it does not necessarily come to mind when discussing higher order thinking, until they are prompted. Pre-service mathematics teachers described higher-order thinking that is different from lower-order thinking on the different at elementary thinking and advances thinking, the level of difficulties, conceptual and contextual, and the type of calculation and verification. In accordance with these research findings, Thompson (2008) states that teachers misinterpret higher-order thinking level of Bloom's Taxonomy. Teachers define higher-order thinking as problem-solving, finding a pattern; interpret information and conceptual understanding. In contrast, most of the teachers define higherorder thinking based on characteristics such as; a) a number of measures "necessary" to solve tasks, (b) level of difficulty, or (c) algebra as subjects that create higher order thinking. Cognitive Levels of Bloom's Taxonomy are used in learning activity objectives. The misconceptions in the formulation of learning objectives provide the competencies achievement that is wrong direction anyway. The opinions of Coffman (2013) and Thompson 
(2008) supports the results of this study reveal that Blooms' Taxonomy often heard even allow potential teachers but not understood properly. Pre-service mathematics teachers identify the higher-order thinking test in accordance with their conception which is described above. It seems that the first and the second section of test items are identified by preservice mathematics teachers at applying level. This is consistent with Harpster (1999), which revealed that mathematics teachers have a mistake perception about higher-order thinking as lower-order thinking.

The mistaken understanding impact of the preservice teachers of higher-order thinking and lower-order thinking is that the ability to create the problem will be low. Saeed \& Naseem (2016) reveal question papers were largely assessing students' lower cognitive abilities (knowledge and comprehension); a few items were assessing higher cognitive abilities (application and analysis). Moreover, Hamafyelto, Hamman-Tukur, Hamafyelto (2015) in their research found there were significant relationships between teachers of commerce competence and content validity, the areas of teachers' competence in constructing examination questions was low. It was found that teachers concentrated on the lower levels of the cognitive domain (remembering, understanding applying). Both of these opinions provide the same idea that many teachers are still inclined to make problems at the low levels. The fact that teachers are only able to make a problem with low levels can be seen from the ability of preservice teachers who also have the wrong conception of higher-order thinking and lower-order thinking.

The higher-order thinking processes that occur in the process of solving mathematical problems are characterized by the application of multiple criteria, which may not be known in advance (Rubin \& Rajakaruna, 2015). As a mathematical process with many criteria, higher order thinking requires linking ideas, concepts, and disciplinary content is an underused yet effective educational strategy (Richland \& Begolli, 2016). It is certainly different from the conception of preservice mathematics teacher in this study. The misconceptions of higher order thinking in Bloom's Taxonomy impact on the development of mathematical thinking ability. The development of mathematical thinking ability is the purpose of the current mathematics education (Kaya \& Aydin, 2016; Katagiri, 2004). The development of mathematical thinking ability is formulated in the objectives of learning activities.

Pre-service mathematics teachers use Bloom's Taxonomy to develop learning indicators but often not aligned with the formulation of test items. Sometimes, tests items are not aligned with learning indicator. Pre-service mathematics teachers just introduced the similar types of problems that are more conditioned the cognitive structure to calculation not thinking. In addition, educators have limited knowledge and creativity in developing test items that vary according to the cognitive level of Bloom's Taxonomy. Test items which are tested also based on a textbook that allows students to learn with the existing standard procedures. Kocakayaa \& Kotluka (2016) explained the agreement in interpretation of standards has to increase, especially for teachers, to allow all students a fair chance to attain the same standards regardless of teachers and schools. The low levels of inter-and intra-judge consistency for the teachers may have negative effects on students' learning, on fairness in assessments.

Ryan \& McCrae (2006) described the errors and misconceptions made by pre-service teachers were used here to inform either personal development or collective treatment during preservice teacher education. Teacher errors deserve attention not least to avoid transfer to children in schools. Errors provide opportunities for pre-service teachers to examine the basis of their own understanding so that knowledge can be reorganized and strengthened. 
Teachers' misconceptions are caused they have a limited understanding of Bloom's Taxonomy. In education, standards have to be interpreted, for planning of teaching, for development of assessments and for alignment analysis (Näsström, 2009). Here, the understanding of the Blooms'Taxonomy correctly become very important in the development of students' thinking skills.

\section{CONCLUSION}

Based on results and discussion above, it can be concluded that: (1) Preservice mathematics teachers have wrong conceptions of higher-order thinking. The preservice mathematics teachers identified higher-order thinking questions type according to elementary and advanced level thinking conception, the level of difficulties, conceptual and contextual, as well as the type of calculation and verification. This conception did not follow the description of lower-order and higher-order thinking as the different cognitive level in procedural or nonprocedural, algorithm or nonalgorithm problem solving; (2) most of the preservice mathematics teachers categorize six cognitive levels at the lower-order and higher-order thinking level correctly except at the applying level, preservice mathematics teachers placed it at the higher-order thinking level; (3) preservice mathematics teacher tend to made the wrong identification of the test questions that were included in the lower-order and higher-order thinking. The wrong conception of lower-order and higher-order thinking lead the preservice teachers to identification results misconception.

According to conclusion described above, there are suggestions and recommendations as follow; (1) Preservice mathematics teachers should be provided with better understanding of cognitive levels of Bloom's Taxonomy, especially the characteristics of each level, attributes attached to each level and math skills, to be part of the higher-order and lower-order thinking level, and other skills relevant to math; (2) Preservice mathematics teachers should be familiarized of higher-order thinking questions start from their first-year of study. The purpose of this attempt is to inform pre-service teachers the type of higher-order thinking, to distinguish and develop insight to think outside the context, divergent, critically and creatively; (3) The preservice mathematics teachers should be trained to develop higher-order thinking level questions. Thus in the future, they will be able to creatively develop nonroutine test items.

\section{ACKNOWLEDGMENTS}

I would like to thank the Third-Year Students of Mathematics Education Department at Nusa Cendana University, who have taken the time been the subject of research and fill this instrument, without their help this work would never have been possible.

\section{REFERENCES}

Anderson, L. W., \& Krathwohl, D. R. (2001). A Taxonomy for learning, teaching, and assessing: A revision of Bloom's taxonomy of educational objectives. New York: Longman Publishing.

Bloom, B. S., Engelhart, M. D., Hill, H. H., Furst, E. J., \& Krathwohl, D. R. (1956). The taxonomy of educational objectives, the classification of education goals, handbook I: cognitive domain. New York: David McKay Company. 
Bookhart, S. M. (2010). How to assess higher-order thinking skills in your classroom. Alexandria: ASCD.

Coffman, D. M. (2013). Thinking about thinking: an exploration of preservice teachers' views about higher order thinking skills. University of Kansas: Unpublished Doctoral Dissertation.

Delima, N. (2017). A relationship between problem solving ability and students' mathematical thinking. Infinity, 6(1), 21-28.

Hamafyelto, R. S., Hamman-Tukur, A., \& Hamafyelto, S. S. (2015). Assessing teacher competence in test construction and content validity of teacher made examination questions in Commerce in Borno State, Nigeria. Education, 5(5), 123-128.

Harpster, D. L. (1999). A study of possible factors that influence the construction of teachermade problem the assess higher-order thinking skills. Montana State UniversityBozeman: Unpublished Doctoral Dissertation.

Hendriana, H. (2017). Senior high school teachers' mathematical questioning ability and metaphorical thinking learning. Infinity, 6(1), 51-58.

Herlina, E. (2015). Meningkatkan advanced mathematical thinking mahasiswa. Infinity, 4(1), 65-83.

Katagiri, S. (2004). Mathematical thinking and how to teach it. CRICED: University of Tsukuba.

Kaya, D., \& Aydin, H. (2016). Elementary mathematics teachers' perceptions and lived experiences on mathematical communication. Eurasia Journal of Mathematics, Science \& Technology Education, 12(6), 1619-1629.

Kocakayaa, S., \& Kotluka, N. (2016). Classifying the standards via revised bloom's taxonomy: a comparison of pre-service and in-service teachers. International Journal of Environmental \& Science Education, 11(18), 11297-11318.

Lewis, A., \& Smith, D. (1993). Defining higher-order thinking. Theory into Practice, 32(3), 131-137.

Miri, B., David, B. C., \& Uri, Z. (2007). Purposely teaching for the promotion of higher-order thinking skills: A case of critical thinking. Research in science education, 37(4), 353369.

Murray, E. C. (2011). Implementing higher-order thinking in middle school mathematics classrooms. University of Georgia: Unpublished Doctoral Dissertation.

Näsström, G. (2009). Interpretation of standards with Bloom's revised taxonomy: a comparison of teachers and assessment experts. International Journal of Research \& Method in Education, 32(1), 39-51.

Pegg, J. (2010). Promoting the acquisition of higher-order skills and understandings in primary and secondary mathematics. Research Conference 2010 (pp. 35-38). Melbourne: Crown Conference Centre.

Richland, L. E., \& Begolli, K. N. (2016). Analogy and higher order thinking: learning mathematics as an example. Behavioral and Brain Sciences, 3(2), 160-168.

Rubin, J., \& Rajakaruna, M. (2015). Teaching and assessing higher order thinking in the mathematics classroom with clickers. International Society of Educational Research, 10(1), 37-51. 
136 Samo, Pre-Service Mathematics Teachers' Conception of ...

Ryan, J., \& McCrae, B. (2006). Assessing Pre-Service Teachers' Mathematics Subject Knowledge. Mathematics teacher education and development, 7, 72-89.

Saeed, M., \& Naseem, A. (2016). Analysis of secondary grade mathematics question papers of boards of intermediate and secondary education in punjab. Pakistan Journal of Education, 31(1), 1-16.

Thompson, T. (2000). An analysis of higher-order thinking on algebra I end-of-course tests. International Journal for Mathematics Teaching and Learning, 12, 1-36.

Thompson, T. (2008). Mathematics teachers' interpretation of higher-order thinking in bloom's taxonomy. International electronic journal of mathematics education, 3(2), 97-109. 